
В ІДЕЯХ І ДОСЛДНИЦЬКИХ ІНТЕРПРЕТАЦІЯХ

\author{
УДК 811.161 \\ DOI: https://doi.org/10.17721/APULTP.2021.42.8-27 \\ Сиитко О.С. \\ ORCID ID: 00000-0002-5593-1334

\section{СУГЕСТИВНИЙ ПОТЕНЦАЛ ПОЛІТИЧНИХ ПРОМОВ ЛІДЕРІВ ДЕРЖАВ}

\begin{abstract}
Анотація. Статтю присвячено аналізу сугестивного потенціалу політичних промов лідерів держав. Доводиться, щуо найкращі зразки цฺих текстів, проголошені у переломні часи розвитку суспільства, демонструють програмувальний ефект, отже побудовані як тексти з ознаками сугестивності. Окреслено важливу специфічну ознаку сугестивного тексту - його особливий ритм. Ритм розглядається як комплексне явище, яке трунтується на співмірному чергуванні чи повторенні будь-яких елементів (формальних та змістових). Відповідний ритм тексту політичної промови базується на лексичному та (ширше) смисловому повторі ключових вербалізаторів домінантних смислів, щуо об'єднуються у дві опозиційні функиіонально-текстові групи, а також на граматичному (морфологічному та синтаксичному) повторі або паралелізмі, фонетичному повторі, який супроводжує лексико-семантичний. Такий повтор підпорядкований комунікативно-прагматичній меті сугестора - закріпленню домінантних смислів. Важливим засобом сугестії $\epsilon$ емочіогенні означення (або кваліфікатори), які спрямовані на емочійне "зарядження" цільової аудиторії. Тексти політичних промов містять елементи урочистої риторики, пафосного звертання до найвищих сакральних сил тощь. Політичні промови лідерів держав стають потужним стимулом для розгортання важливих для суспільства наративів, які сприяють утвердженню того чи іншого вектору політичного розвитку суспільства. Змістовна політична промова, побудована з урахуванням сугестивних технік та прийомів, $\epsilon$ ефективним інструментом реалізащії владного впливу на цільову аудиторію, засобом формування суспільної думки, створення настрою в соціумі. Політичний лідер виконує, таким чином, роль авторитетного комунікатора, який впорядковує, структурує картину світу людини $i$ здійснюе протидію комунікативним війнам та хаотизациї свідомості людей.
\end{abstract}


Ключові слова: політична промова, сугестивний потенціал, ритм сугестивного тексту, емоціогенні означення, політичний наратив.

Інформація про автора: Снитко Олена Степанівна - доктор філологічних наук, професор; завідувач кафедри російської філології; Інститут філології; Київський національний університет імені Тараса Шевченка.

Електронна адреса: elenasnytko@ukr.net

\author{
Olena S. Snytko \\ ORCID ID: 0000-0002-5593-1334
}

\title{
SUGGESTIVE POTENTIAL OF POLITICAL SPEECHES OF STATE LEADERS
}

Abstract. The paper examines the suggestive potential of political speeches of state leaders. The author argues that the greatest political addresses given at turning points in history demonstrate a programming effect and, consequently, are intended as texts with suggestive features. The current study proves that rhythm is the essential feature of a suggestive text. The rhythm is a complex phenomenon built on the balanced alternation or repetition of certain elements (formal and semantic). The distinctive rhythm for political address is established via lexical and, broader, semantic repetition of key verbal elements carrying dominant meanings which comprise two opposite functional textual groups via grammatical (morphological and syntactic) patterns or parallelism, accompanied by phonetic repetition. Such repetition serves the communicative-pragmatic purpose of the suggestor, namely, to consolidate the dominant meanings. The results of this study indicate that emotiogenic attributes (or qualifiers) aimed at emotional "charging" of the target audience are the primary means of suggestion. The texts of political speeches contain the elements of solemn rhetoric and pathetic appeal to the sacred forces. Political addresses of state leaders provide a strong impetus for creating meaningful public narratives favouring one or another political course of society. Furthermore, an informative political speech, which employs suggestive techniques, serves as a potent tool to exercise power over the target audience and as a means to shape public opinion and influence the mood in society. Finally, the political leader plays the role of an authoritative communicator who organizes, structures the individual's picture of the world, helps to resist communicative warfare and gives people a sense of order in a life of chaos.

Key words: political speech, suggestive potential, rhythm of suggestive text, emotiogenic qualifier, political narrative. 
Information about the author: Snytko Olena Stepanivna - Doctor of Philology, Professor; Head of the Department of Russian Philology; Institute of Philology; Taras Shevchenko National University of Kyiv.

E-mail: elenasnytko@ukr.net

\author{
Снитко Е.C. \\ ORCID ID: 00000-0002-5593-1334
}

\title{
СУГГЕСТИВНЫЙ ПОТЕНЦИАЛ ПОЛИТИЧЕСКИХ РЕЧЕЙ ЛИДЕРОВ ГОСУДАРСТВ
}

\begin{abstract}
Аннотация. Статья посвящена анализу суггестивного потенциала политических речей лидеров государств. Доказывается, что лучшие образиы этих текстов, провозглашенных в переломные времена развития общества, демонстрируют программирующий эффект, следовательно, построены как тексты с признаками суггестивности. Определен важнейтий специфический признак суггестивного текста - его особый ритм. Ритм рассматривается как комплексное явление, основанное на соразмерном чередовании или повторении каких-либо элементов (формальных и содержательных). Соответствующий ритм текста политической речи базируется на лексическом и (шире) смысловом повторе ключевых вербализаторов доминантных смыслов, которые объединяются в две оппозиционные функиионально-текстовые группы, а также на грамматическом (морфологическом и синтаксическом) повторе или параллелизме, фонетическом повторе, который сопровождает лексикосемантический. Такой повтор оказывается подчиненным коммуникативно-прагматической иели сугzестора - закреплению доминантных смыслов. Важным средством сугzестии выступают эмоииогенные определения (или квалификаторы), которые направлены на эмочиональное "заряжение" целевой аудитории. Тексть политических речей содержат элементы торжественной риторики, пафосного обращения к высшим сакральным силам и тому подобное. Политические речи лидеров государств становятся мощчным стимулом для развертыввания важных для общества нарративов, которые способствуют утверждению того или иного вектора политического развития сочиума. Содержательная политическая речь, построенная с учетом суггестивных техник и приемов, является эффективным инструментом реализации властного воздействия на иелевую аудиторию, средством формирования общественного мнения, создания настроения в сочиуме. Политический лидер выполняет, таким образом, роль авторитетного коммуникатора, который упорядочивает, структурирует картину
\end{abstract}


мира человека и осуществляет противодействие коммуникативным войнам и хаотизачии сознания людей.

Ключевые слова: политическая речь, сугzестивный потенциал, ритм суггестивного текста, эмочииогенные квалификаторы, политический нарратив.

Информация об авторе: Снитко Елена Степановна - доктор филологических наук, профессор; заведующий кафедрой русской филологии; Институт филологии; Киевский национальный университет имени Тараса Шевченко.

Электронный адрес: elenasnytko@ukr.net

Сучасне постіндустріальне суспільство 3 гігабайтами інформаційних потоків, які проходять крізь мозок людини, 3 розвитком комп'ютерних технологій, високою швидкістю доступу до інформації водночас $\epsilon$ епохою симулякрів та постправди. У соціумі постійно відбувається не моделювання, а конструювання правди за чіткими лекалами, створюється медіареальність, яка є зручною та приємною для користувача [12]. I як результат - відбувається хаотизація свідомості людини, що губиться в пошуках та осмисленні реального світу, який підміняється віртуальним.

Хаотичність життєвих подій, множинність їх інтерпретацій спонукають людину до пошуку певних взірцевих алгоритмів розуміння реальності, які продукуються моральними авторитетами, суспільними лідерами, державними діячами, яким довіряють і за якими йдуть. Можна говорити про ключову роль комунікаторів, які спрямовують відповідні вектори інтерпретації інформації і (разом із тим) сприяють формуванню так званої "суспільної думки". Непересічні особистості, які стають лідерами держав (та спічрайтери, яких вони залучають), в ідеалі мають володіти технологіями впливу на суспільство в цілому та конкретну цільову аудиторію.

Досвід американського політичного красномовства $\epsilon$ показовим та цікавим щодо застосування різних технологій впливу. А. Литвин у своїй розвідці згадує відомий перелік 3 25 найвідоміших політичних промов, які вплинули на долю людства. Цей список був опублікований в журналі Vital Speech of the Day на підставі аналізу 17 тисяч виступів, проголошених 
31934 року. Серед найкращих промов, які потрясли світ, було відзначено промову президента США Ф. Рузвельта про вступ США у Другу світову війну, промову президента США Д. Буша-мол. про терористичний акт 11 вересня 2001 року та початок глобальної війни з тероризмом та ін. [7, с. 141].

Хрестоматійним прикладом політичного красномовства вважається промова президента США А. Лінкольна (19 листопада 1863 року) на церемонії відкриття Національного кладовища в Геттісбурзі ${ }^{1}$. У промові згадується одна 3 найбільш кровопролитних битв Громадянської війни, у якій загинули десятки тисяч солдатів, що освятили своїм життям ідею існування та розвитку США як молодої та прогресивної держави. У тексті промови, який складається 3272 слів, об'єднаних у 10 речень, викладено філософію державного устрою США. Ключовими словами, у які вкладаються головні домінантні смисли промови, були такі: "нація (народ) отримає державу як джерело свободи, державу, створену народом і для народу". Дослідники підкреслюють надзвичайний вплив, який

\section{${ }^{1}$ Геттісбурзька промова (1863) А.Лінкольна}

Вісімдесят сім років тому наші батьки створили на цьому континенті нову націю, засновану в дусі свободи і вірну принципам, що всі люди створені рівними.

Тепер ми залучені в велику Громадянську війну, яка доведе, чи зможе довго витримати ця нація чи будь-яка інша нація, таким чином народжена i віддана тій же ідеї.

Ми зустрілися на великому полі битви цієї війни. Ми прийшли сюди для того, щоб освятити частину цього поля як місце останнього заспокоєння для тих, хто віддав свої життя заради того, щоб ця нація могла жити. Цим ми лише гідним чином виконуємо свій обов'язок. Але ми не можемо в повному значенні ні відкрити, ні освятити, ні вшанувати цю землю. Хоробрі люди, живі і мертві, які билися тут, вже освятили іiі, і не в нашій слабкій владі що-небудь додати або відняти. Світ відзначить недовгою пам'яттю те, що ми тут говоримо, але він ніколи не зможе забути те, що здійснили ці люди. Для нас, що живуть, найкращий спосіб вшанувати пам'ять загиблих - присвятити себе з подвоєною відданістю завершенню тієї справи, яку вони так благородно почали, за яке вони тут воювали і за яке 3 честю померли, віддавши все, що могли.

Ми повинні урочисто постановити, що ці смерті не будуть марними, і наша нація під заступництвом Бога отримає нове джерело свободи, і цей уряд 3 народу, створене народом і для народу, не помре на землі. 
здійснила ця промова на реципієнтів свого часу [4], силу цього впливу відчуваєш і сьогодні.

Безумовно, перлокутивний ефект кожної політичної промови залежить від багатьох чинників - вербалізації (вдалої чи не дуже) основних думок політичного лідера, ступеня експресивності та емоційності тексту, врахування в ньому етнічно-ментальних рис адресата (цільової аудиторії), харизматичності самого промовця, проте, як свідчить аналіз, резонанс політичної промови забезпечується передусім сугестивним потенціалом проголошеного тексту [3; 9].

У сучасній інтерпретації сугестія - "це процес впливу на психічну сферу, пов'язаний 3 некритичним сприйняттям та засвоєнням певної інформації" [11, с. 43]. За визначенням відомого російського психотерапевта В. Бехтєрєва, сугестія відбувається без участі волі сприймаючої особи і нерідко навіть без ясного з ії боку усвідомлення [1].

Наприкінці XX століття до універсальних сугестивних текстів відносили передусім замовляння, молитви, мантри, формули гіпнозу та аутотренінгу. Сугестивною ознакою цих текстів вважалася "гармонія між семантичними та фоносемантичними їх параметрами, універсальність їх звукоритмічного впливу" (правда, без чіткого тлумачення суті поняття) [15, с. 119-120]. Проте вже тоді, на перших етапах становлення сугестивної лінгвістики, було поставлено питання про свідоме моделювання текстів (лікувальних, рекламних, навчальних, політичних) 3 урахуванням фактору адресата та комунікативних ситуацій загалом. Тексти, які мають забезпечити вплив на особистість чи цільову аудиторію, мають бути побудовані з використанням елементів сугестії. Значно пізніше було окреслено важливу специфічну ознаку сугестивного тексту (терапевтичного або патогенного) чи тексту 3 ознаками сугестивності - його особливий ритм $[2 ; 3 ; 5 ; 9 ; 10]$. Ритм у сугестології розглядається як комплексне явище, яке базується на "закономірному чергуванні чи повторенні будьяких елементів та співмірності, яка грунтується на цьому чергуванні чи повторенні", а також - як "динамічний фактор 
Актуальні проблеми української лінгвістики: теорія і практика

текстотворення", який передбачає не лише закономірне повторення чи чергування формальних елементів, певну звукобуквенну їх структурацію, але й відповідну співмірну організацію лексичних i граматичних елементів тексту, підпорядковану комунікативно-прагматичній меті сугестора закріпленню домінантних смислів (i цей другий підхід $\epsilon$ органічним для сучасних досліджень механізмів сугестії) [2].

Тексти політичних промов лідерів держав, проголошені у переломні часи розвитку суспільства, мають демонструвати програмувальний ефект, отже мають бути побудовані як тексти з ознаками сугестивності.

Дамо визначення ключовому поняттю. Політична промова, на думку лінгвістів, - це заздалегідь підготовлений усний публічний виступ, який має на меті переконання цільової аудиторії у важливості певних політичних дій, текст, у якому не тільки окреслюється політична ситуація, але й визначається перспектива політичних змін [8, с. 4; 13, с. 235].

За своєю інтенцією текст промови - це гострополітичний виступ із позитивними та негативними оцінками, "ефективний засіб для визнання та демонстрації лідерства" 3 намаганнями переконати людей та повести їх за собою [13, с. 236]. Тобто використання сугестивних прийомів впливу (разом із вмінням оратора вдало роз'яснювати та тлумачити факти, використовувати засоби експресії та емотивної оцінки, паралінгвальні засоби комунікації тощо) забезпечує ефективність виступу. Зрештою, політична промова - це засіб ефективної реалізації впливу на аудиторію, засіб формування настрою реципієнтів.

Розглянемо тексти кількох політичних промов крізь призму категорій сугестивної лінгвістики.

Одним із найпомітніших явищ у суспільно-політичному житті України останніх п'яти років була промова Дж. Байдена (на той час - віцепрезидента США), виголошена 8 грудня 2015 року у Верховній Раді України, ця промова мала великий політичний та емоційний резонанс, вона тривалий час активно 
обговорювалась у суспільстві, тобто здійснила значний вплив на український соціум ${ }^{2}$.

Пор. коментарі українських ЗМI 2015 року щодо промови Д. Байдена:

(1) Віце-президент США Джозеф Байден виступив із промовою 3 трибуни Верховної Ради. Цей півгодинний виступ низка експертів уже встигли назвати історичним... У своїй промові Байден згадав Помаранчеву революцію і Революцію гідності, провів паралелі з історією США, а також закликав українських політиків до єдності і відповідальності, вкотре звернув увагу на боротьбу з корупцією та на завершення процитував Тараса Шевченка ${ }^{3}$.

(2) Обраний 46-м президентом США Джо Байден у 2015 році приїздив до України як тодішній віце-президент Америки і виступив із емоційною промовою із трибуни у Верховній Раді. Його промову охрестили історичною. У виступі Байден назвав два головних виклики для України - вторгнення Росії і корупція, яку він назвав "раковою пухлиною" України

Проаналізуємо основні сугестивно детерміновані ознаки тексту політичної промови, передусім відповідну співмірну організацію лексичних і граматичних елементів, спрямовану на закріплення домінантних смислів: "подіï в Україні $\epsilon$ доленосними, кожен українець відповідає перед історією за свій вибір и свою позичію, світ підтримує $i$ буде підтримувати європейський вибір Украӥни, ї боротьбу за свободу проти агресора, світ на боці Украӥни".

Усі ключові (високочастотні) слова тексту об'єднуються у великі за обсягом ряди мовних та контекстуальних синонімів, що сприяє виникненню внутрішньотекстових парадигм, які взаємодіють між собою та утворюють функціонально-текстові групи. Як свідчить аналіз, "центром групи стає найчастотніша,

2 Повний текст промови див.: https://glavcom.ua/country/politics/istorichnapromova-baydena-u-radi-pyat-rokiv-tomu-prigadujemo-yak-ce-bulo-716656.html

${ }^{3}$ URL: https://www.radiosvoboda.org/a/27414766.html

4 URL: https:/glavcom.ua/country/politics/istorichna-promova-baydena-u-radipyat-rokiv-tomu-prigadujemo-yak-ce-bulo-716656.html 
Актуальні проблеми української лінгвістики: теорія і практика

найбільш значуща лексема (іноді - лексеми), яка набуває статусу ключової, входячи в найбільшу кількість протиставлень та відповідностей" [2].

До складу функціонально-текстової групи входить "основна номінативна одиниця, яка може розглядатися як ім'я текстової групи, іiі синоніми, словотвірні деривати, іiї семантичні асоціати, а також лексика, яка відбиває семантичну диференціацію імені (назви роди-видових корелятів, назви частин явища, його властивостей)" [2]. Завдяки високочастотному повтору відповідних співвідносних за семантикою лексичних одиниць утворюється ритмо-хвильова структура тексту, забезпечується ефект закріплення певних домінантних смислів.

Аналіз частотності лексем у відповідному тексті був проведений за допомогою ресурсів Електронного корпусу української мови ${ }^{5}$, який розроблений в Інституті філології Київського національного університету імені Тараса Шевченка.

У тексті промови можна виділити дві основні функціонально-текстові групи, які взаємодіють між собою.

I. "Україна та українці" (народ України, ваша країна, Украйна і ви, молоді жінки і чоловіки, щуо заполонили Майдан, люди, які вимагали, щуоб їхні голоси були почуті і підраховані чесно, які досягли иьього, люди, у яких було яскраве полум'я надіі на створення нової України, люди, які почали нову револючію Револючію Гідності, люди, які мріяли про шлях до майбутнього, люди, які залишалися на Майдані $i$ вдень, $i$ вночі, брати $\boldsymbol{i}$ сестри, десятки тисяч людей, щуо приносили допомогу на Майдан, протестувальники, украӥниі, які вимагали другий шанс на свободу $і$ краще майбутнє, Небесна сотня, нова сім'я; сучасна Украӥна - че велика можливість, велика невизначеність, високі очікування).

${ }^{5}$ URL: http://www.mova.info 
II. "Світ і ми (США)" (ми на Заході пам'ятасмо Помаранчеву революиію, ми знаємо сьогодні [про подї в Україні], ми бачили [як згорталися реформи], світ був приголомшений [подіями в Украӥні], світ дивився, світ і люди продовжували спостерігати за вами; люди сподіваються на ваш успіх, ми об'єднали світ у підтримиі України, Сполучені Штати продовжують стояти разом з Украӥною проти російської агресії, ми надаємо допомогу силам безпеки Украӥни,

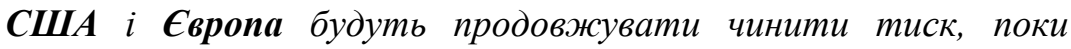
Москва не виконає Мінські угоди, США стоять поруч з вами у цій боротьбі). Як бачимо, текст містить велику кількість конструкцій спільності і довіри.

Лексеми, які вербалізують зміст основних функціональнотекстових груп, демонструють високий показник абсолютної частотності: ви - 43, вони - 24, люди - 23, Україна - 23, ваш 23, ми -22, свій-18, краӥна - 17, світ - 15 .

Принагідно відзначимо, що особливої ваги у дискурсі промови набуває директивна форма висловлювання. Так, спрямований вплив на психіку реципієнта (українців передусім) досягається за допомогою низки повторюваних модальних конструкцій повинності: Все - y ваших руках, ви можете повернути колесо історії, украӥнці повинні керувати своєю долею, Украйна не може собі дозволити втратити надію, ви повинні зробити все, ви повинні проводити реформи. Це - ваш обов'язок. Це - ваш час, ваша відповідальність, кожного з вас, це ваша історична можливість, ви відповідаєте на виклик історії, вас будуть судити ваші онуки і ваша історія.

Надвисокою $є$ абсолютна частотність лексеми "повинний", індекс частотності - 24 .

Смислова взаємодія двох функціонально-текстових груп забезпечує установку адресата на позитив і завершується формулою звертання до найвищих сакральних сил у фінальній частин тексту, демонструючи динамічну кореляцію з висхідним вектором руху: "Нехай Бог благословить два намі народи $i$ 
Актуальні проблеми української лінгвістики: теорія і практика

нехай Бог благословить $і$ захистить наші війська!" (замість "ми" i "ви" з'являється спільне визначення - наші - "наші народи" $i$ "наші війська". Таким чином, використовується ще один засіб позитивного впливу - окреслення "кола своїх", до якого входить Україна. Власне це співвідношення основних функціонально-текстових груп віддзеркалює основний меседж промови: європейський вибір України є визначальною подією для сучасного світу, світ підтримує українців. Тому текст промови заряджає адресата емоційно [14]. На це спрацьовують й емоціогенні означення, які використовуються в тексті промови передусім для характеристики народу України, який переживає переломний момент історії: люди, які вимагали, щоб їхні голоси були почуті і підраховані чесно, які досягли ијього, люди, у яких було яскраве полум'я надї̈ на створення нової України, люди, які мріяли про шлях до майбутнього, десятки тисяч людей, щзо приносили допомогу на Майдан, українці, які вимагали другий шанс на свободу і кращзе майбутнє.

Емоціогенні означення значно підсилюють "роботу" ритму тексту.

Емоційне зарядження характеризується переходом адресата в особливий психічний стан піднесення, задоволення, на базі чого ефективно проходить закріплення домінантних смислів.

Крім лексичного повтору (Ми бачили, як олігархи були відсторонені від влади, а потім вони поверталися. Ми бачили, як реформатори переслідувалися в результаті політичної помсти. А світ на все це дивився. А світ ілюди продовжували спостерігати. Навіть тоді, коли протестувальників зустріли снайперським вогнем з дахів будинків. Світ дивився), який у промові Дж. Байдена відіграє ключову роль, активно використовуються такі засоби сугестивного впливу, як паралельні конструкції, тобто граматичний повтор (Mu допомагаємо з навчанням і надаємо допомогу силам безпеки України. Ми об'єднали світ і покладаємося на світ у підтримиі Украйни) та протиставлення (Люди були налякані, вони 
заціпеніли від жаху, коли мирні протести на Майдані у Києві зіткнулися з насильством. Але люди залишалися на Майдані $\boldsymbol{i}$ вдень, $\boldsymbol{i}$ вночі. 3 часів середніх віків дзвони Михайлівського собору підняли тривогу, щоб закликали украӥнців приєднатися до їх братів $i$ сестер на Майдані. Десятки тисяч людей відгукнулися на цей заклик).

Показово, що навіть синхронний переклад промови в Верховній Раді здійснювався американськими фахівцями, що (як можна передбачати) враховували необхідність правильного відтворення українською мовою сугестивних засобів, закладених у структурі тексту.

Звернемось до аналізу політичних промов сучасних українських лідерів, Ці тексти переважно також готуються спічрайтерами, які мають володіти методиками сугестивного впливу та відповідно враховувати певні параметри побудови текстів. Проаналізуємо, наприклад, один із найсильніших текстів політичних промов українських державних діячів промову Президента В. Ющенка в День пам'яті жертв голодоморів та репресій. Промову біло виголошено 24 листопада 2007 року на Михайлівській площі у Києві ${ }^{6}$.

Аналіз частотності лексем (загальна кількість у тексті 1206), встановлення ключових слів та пошук т.зв. семантичного ядра, яке проводилося за допомогою електронного сервісу $\mathrm{ADVEGO}^{7}$, дозволяє встановити не тільки корпус означених лексичних елементів, але й побачити кілька їх функціональнотематичних груп, які взаємодіють у структурі тексту промови. Ці групи не рівноцінні за своїм обсягом:

I. "ми ( українці, український народ, Україна)".

До складу цієї групи входять не тільки основні номінативні одиниці, які розглядаються як ім'я текстової групи, iii синоніми (загальномовні та контекстуальні), їх семантичні асоціати, перифрастичні словосполучення, а також лексика, яка

${ }^{6}$ Повний текст див.: http://old.loga.gov.ua/calendar/golod/news/2007/12/05/ main_1241.html; відеозапис див.: https://www.youtube.com/watch?v=TiSqeqsbaC8

${ }^{7}$ URL: https://advego.com/text/seo/ 
Актуальні проблеми української лінгвістики: теорія і практика

відбиває семантичну диференціацію імені (назви родо-видових корелятів, назви частин явища, його властивостей):

"народ, український народ, Украӥна, ми, вони, мільйони, нація, жертви, Украӥна, діди, батьки, брати, сестри, рідні; найдорожчі, які знайшли свій спокій і тихо заснули на руках у Господа; кожна душа, кожна жертва, кожний мученик, перші жертви; розтерзані, покалічені, принижені поети, національна творча інтелігенція, яка опинилася в центрі масових арештів $i$ терору, пошматований та підмінений народ, украйнське селянство".

Найчастотніші елементи - народ (він) -15, украӥнський народ, нація, Украӥна-15, мільйони- 7, жертва-5.

У тексті промови наявні сильні емоціогенні кваліфікатори елементів першої групи:

"мільйони невинних людей, сотні тисяч родів, вимерлих сіл, невідспіваних дуи, закатованих, замордованих, непохованих доль. Вони хочуть додому. Вони бачать иі вогники. Вони вірять нам. Бо ми - це їх не непрожите життя; розтерзані, покалічені, принижені поети, начіональна творча інтелігенція, яка опинилася в центрі масових арештів $i$ терору, пошматований та підмінений народ"

II. "вони - тоталітарний комуністичний режим":

"голодомор, голод, страх, терор, зло, геноцид, головний убивия, звиродніла зграя, яка не мала жалю до жодного народу, яка залила кроваві ріки; терор, який був розгорнутий планомірно $i$ послідовно, Йосиф Сталін, вбивці, які конфіскували продовольство а перетворили ( Украӥну) на гетто голоду, вони - ие тоталітаризм, більшовизм, людиноенависництво".

Найчастотніші лексичні елементи, які входять до другої групи, - голодомор -5 , голод -4 , страх -3 , террор - 3 , геноиид - 2 . 
Чисельне домінування лексичних елементів першої ФТГ зумовлено, на наш погляд, фактором адресата, адже промова $\epsilon$ зверненням саме до України, української нації передусім, вона враховує ментально-культурні риси та історичну пам'ять цільової аудиторії. Проте чисельність лексичних повторів слів, які спрямовані на вербалізацію домінантних смислів, $€$ дуже помірною. Часткова "розмитість" цієї групи (головним чином другої групи), нещільність ключових слів значною мірою компенсується наявністю сильних емоціогенних кваліфікаторів: "Проти нас ішло зло. Його ймення - геноцид. Свідома, спланована і втілена спроба упокорення нації. Його організатор i виконавець - тоталітарний комуністичний режим. головний убивця, звиродніла зграя, яка не мала жалю до жодного народу, яка залила кроваві ріки; терор, який був розгорнутий планомірно і послідовно, вбивці, які перетворили (Украйну) на гетто голоду; Голодомор - не просто біль і рана. Це - чорна діра нашої історії, яка могла безповоротно поглинути не тільки Україну, але й будь-яку найменшу надію на життя".

Відносно невисока щільність лексичних повторів (передусім ключових слів, що вербалізують домінантні смисли), наприклад, у порівнянні 3 текстом промови Дж. Байдена, підтверджується й такими фактами: значно більша за "площею", обсягом промова Дж. Байдена сукупно складається зі значно меншої кількості слів - 793 слів, а промова В. Ющенка зі значно більшої - 3 1206. Проте у промові В. Ющенка наявні також і такі ознаки сугестивності, як граматичний повтор, в тому числі синтаксична однотипність (паралелізм) побудови речень у певних фрагментах тексту:

Я згадую розтерзаних, покалічених, принижених Твойх поетів, мій народе <..>. Я згадую Твою національну <..> інтелігенцію, яка опинилася в центрі масових арештів. $<\ldots>\boldsymbol{g}$ згадую наші знищені иеркви і духовенство. Я згадую колосальні $і$ немислимі жертви воєн. <...> Мос сьогоднішне слово - не реквісм. Мос слово - це гімн украӥнському народові, чия сила незнищенна. <..> Ми вистояли завдяки мільйонам чесних людей.. Ми вистояли, бо воля, правда і життя творилися всіма. Ми перемогли у вирішальній битві зі злом. 
Актуальні проблеми української лінгвістики: теорія і практика

Співвідношення основних функціонально-текстових груп віддзеркалює основний меседж промови: "незважаючи на геночии, до якого вдався тоталітарний комуністичний режим, сила украӥнського народу незнищенна; ми маємо відродити націю як єдиний здоровий організм". Цей меседж і можна вважати домінантними смислами промови.

Спрямований вплив на психіку реципієнта (українців передусім) досягається за допомогою низки повторюваних модальних конструкцій повинності:

"Сьогодні ми повинні перемогти у вирішальній справі повернути Україні саму себе. Ми повинні одягнути Украӥну у чисту сорочку і прибрати з ї тіла символи тоталітарного режиму - можливо, нехай не за рік. Ми мусимо ретельно віднайти і зберегти знання про кожну жертву Великого голоду $i$ встановити національні меморіали. <..> Ми маємо утвердити великий суспільний діалог пам'яті $i$, водночас, діалог перспективи - бо треба йти вперед, жити повноцінним життям великої сучасної європейської держави, діяти $\boldsymbol{i}$ прагнути до справжнього порозуміння".

Фінальна частина промови забезпечує й емоційний пік у їі сприйнятті реципієнтами, бо політичний лідер держави висловлює впевненість у здійсненні поставлених завдань, звертаючись до найвищих сакральних сил 3 проханням захистити майбутнє нескореного народу (прийом, який $€$ типовим для промов американських політичних діячів): "...мu утвердимо своє майбутнє, свій новий демократичний Основний закон, свою свободу, своє право, свою любов одне до одного, до рідної мови, рідної землі $і$ нашої соборної долі. Я прошу в Господа дати нам силу, щзб повернутися до самих себе".

Сучасні українці відповідають за це перед пам'яттю мільйонів знищених співвітчизників:

"Вони вже тут. Вони дуже довго йшли. Мільйони, мільйони, мільйони нас. <..> Це - не сльози. <..> Це посміхається маленький хлопчик на руках у Всевишнього. < ... >ічна пам'ять і слава Украӥні!" 
Промова президента - не реквієм, а "гімн українському народові, чия сила незнищенна". Така інтенція забезпечує емоційне зарядження цільової аудиторії, яка відчуває особливий психічний стан піднесення, що й сприяє ефективному закріпленню домінантних смислів.

Так, П. Михед засвідчує у своїх коментарях саме таку емоційну реакцію на текст промови В. Ющенка та називає двох спічрайтерів, які можуть бути причетними до підготовки тексту промови - філолог В. Федоренко (на той час - провідний спеціаліст МОН України) та Д. Лубківський (на той час керівник Служби підготовки виступів Президента України $)^{8}$.

Як бачимо з порівняння засобів сугестії, які притаманні політичним промовам Д. Байдена та В. Ющенка, зверненим до українського народу та проголошеним у переломні часи розвитку країни, ключовими елементами сугестивного впливу $\epsilon$ специфічний ритм тексту, який базується на лексичному та (ширше) смислову повторі ключових вербалізаторів домінантних смислів, що об'єднуються у дві опозиційні функціонально-текстові групи, граматичному (морфологічному та синтаксичному) повторі або паралелізмі, фонетичному повторі, який супроводжує лексико-семантичний. Повтор підпорядкований комунікативно-прагматичній меті сугестора закріпленню домінантних смислів. Важливим засобом сугестії $\epsilon$ емоціогенні означення (або кваліфікатори), які спрямовані на емоційне "зарядження" цільової аудиторії, тексти політичних промов містять елементи урочистої риторики, пафосного звертання до найвищих сакральних сил тощо.

Політичні промови лідерів держав стають потужним стимулом для розгортання важливих для суспільства наративів, які сприяють утвердженню того чи іншого вектору політичного розвитку суспільства (боротьба за майбутню європейську Україну, вільну від корупції - у Дж. Байдена, курс на відродження української нації як єдиного здорового організму у В. Ющенка).

${ }^{8}$ URL: https://www.facebook.com/100003320779409/ posts/3475636582557000/ 
Як свідчить аналіз текстів політичних промов, які мають місце у сучасному українському політичному дискурсі, нехтування засобами сугестивного впливу призводить до різкого зниження перлокутивного ефекту промови ( іноді катастрофічного), яка не стимулює розвиток суспільної думки, скоріше, - викликає роздратування та зневіру, які породжують хаос думок. Хаос думок, як зазначає Д. Кулеба у своїй книзі [6], $€$ найважливішою ознакою комунікативної війни, керованих атак на свідомість та підсвідомість людей: "Ми живемо в безперервній комунікативній війні. Вона складається і 3 керованих атак з боку зацікавлених сторін (держав, політичних сил, компаній), i 3 некерованих спалахів інформації, що спричиняють інформаційний шторм (чи радше штурм). Із цієї суміші виникає інформаційний хаос. Певний сегмент такого хаосу можна контролювати, але неможливо контролювати весь хаос. Хаос посилюють гарантовані інтернетом безкінечні інтерпретації реальності та нездатність комунікатора повністю контролювати реакцію аудиторії" [6, с. 26].

Змістовна політична промова, побудована 3 урахуванням сугестивних технік та прийомів, $\epsilon$ ефективним інструментом реалізації владного впливу на цільову аудиторію, засобом формування суспільної думки, засобом створення настрою у соціумі. Політичний лідер виконує таким чином роль авторитетного комунікатора, який впорядковує, структурує картину світу людини і таким чином здійснює протидію комунікативним війнам та хаотизації свідомості людей.

\section{ЛITЕРАТУРА}

1. Бехтерев В.М. Внушение и его роль в общественной жизни [Електр. peсурс]. URL : http://www.gumer.info/bibliotek_Buks/Psihol/Behter/ -Vnush 01.php/

$\overline{2}$. Болтаева С.В. Ритмическая организация суггестивного текста [Електр. pесурс]. URL : http://aboutyourself.ru/psivliyan/suggestivniytext.html.

3. Бойчук Е.И. Восприятие ритма прозаического текста. Актуальные вопросы филологических наук. 2011(1). С. 39-44.

4. Гончаренко Е.П. "Іноді лише кілька слів мають надзвичайну силу": переклад та аналіз Геттизберзької промови Авраама Лінкольна. 
Науковий вісник Міжнародного гуманітарного університету. Філологія. 2016. №24(2). С. 110-112.

5. Калита А.А. Суггестивный потенциал ритмической системы прозаического текста. Когниция, коммуникащия, дискурс. 2015. №11. C. $29-44$.

6. Кулеба Д. Війна за реальність: як перемагати у світі фейків, правд і спільнот. Київ: Книголав, 2019. 384 с.

7. Литвин А.В. Історичний аналіз застосування спічрайтингових технологій у політичних комунікаціях США та Росії. Обрії друкарства. 2014. №1(3). С. 138-145.

Ч.4. С. 3-16.

8. Мацько Л.І. Лінгвістична риторика. Наука і сучасність. 1999.

9. Наговицын А.Е. Особенности ритмо-фонетической структуры текста: Смысловое наполнение фонетических знаков. Москва: МПСИ: Флинта, 2005. 408 c.

10. Падалка О.В. Політична промова та іiі просодичні характеритики. Науковий вісник Волинського національного університету імені Лесі Украӥнки. 2012. № 6. С. 66-69

11. Петрик B.M. Сугестивні технології маніпулятивного впливу / В.М. Петрик, М.М. Присяжнюк, Л.Ф. Компанцева та ін. Київ : Науково-видавничий відділ Національної академії СБ України, 2010. $248 \mathrm{c}$.

12. Почепцов Г.Г. Постправда как новый виток развития цивилизации [Електр. ресурс]. URL: https://ms.detector.media/ mediaanalitika/post/22902/2019-05-19-postpravda-kak-novyi-vitokrazvitiya-tsivilizatsii/

13.Самойлова I. В., Подвойська О. В. Лексичні особливості політичних промов. Наукові записки НДУ ім. М.Гоголя. Філологічні науки. 2016(1). С.235-238.

14.Снитко О.С. Інформаційно-психологічне онлайн протистояння у парадигмах лінгвістики впливу. Компаративні дослідження слов'янських мов і літератур. 2016. №31. С.121-136.

15. Черепанова И.Ю. Человек манипулирующий (суггестия в коммуникации). Человек говорящий. Язык, культура, познание. 1995(1). C. 115-124.

16. Brown G. Discourse Analysis. Cambrige: Cambrige Univ. Press, $1983.288 \mathrm{p}$.

17. Jacobsen, K. \& Kerry, T. "The right to lead": Navajo language, dis-citizenship, and Diné presidential politics. Journal of Sociolinguistics. 2020. №24(1). P. 35-54. https://doi.org/10.1111/josl.12380 [in English].

\section{REFERENCES}

1. Bekhterev, V.M. (2016). Suggestion and its role in public life [Vnusheniye i yego rol' $\mathrm{v}$ obshchestvennoy zhizni]. URL: 
http://www.gumer.info/bibliotek_Buks/Psihol/Behter/_Vnush_01.php/ (last access: 28.01.2021) [in Russian].

2. Boltajeva, S.V. (2018). Rhythmic organization of suggestive text [Ritmicheskaya organizatsiya suggestivnogo teksta]. URL: http://aboutyourself.ru/psivliyan/suggestivniy-text.html (last access: 28.01.2021) [in Russian].

3. Boychuk, E.I. (2011). Perception of the rhythm of a prosaic text [Vospriyatiye ritma prozaicheskogo teksta]. Topical issues of philological sciences, (1), 39-44 [in Russian].

4. Goncharenko, E.P. (2016). "Sometimes only a few words have extraordinary power": translation and analysis of the Gettysburg speech of Abraham Lincoln ["Inodi lyshe kil'ka sliv mayut' nadzvychaynu sylu": pereklad ta analiz Hettyzberz'koyi promovy Avraama Linkol'na]. Scientific Bulletin of the International Humanities University. Philology, 24(2), 110112 [in Ukrainian].

5. Kalita, A.A. (2015). Suggestive potential of the rhythmic system of prosaic text [Suggestivnyy potentsial ritmicheskoy sistemy prozaicheskogo teksta]. Cognition, communication, discourse, 11, 29-44 [in Russian].

6. Kuleba, D. [2019]. The war for reality: how to win in the world of fakes, truths and communities [Viyna za real'nist': yak peremahaty u sviti feykiv, pravd i spil'not.]. Kyiv : Knyholav [in Ukrainian].

7. Litvin, A.V. (2014). Historical analysis of the application of speechwriting technologies in the political communications of the United States and Russia [Istorychnyy analiz zastosuvannya spichraytynhovykh tekhnolohiy u politychnykh komunikatsiyakh SHA ta Rosiyi]. Horizons of printing, 1(3), 138-145 [in Ukrainian].

8. Matsko, L.I. Linguistic rhetoric [Linhvistychna rytoryka]. Science and modernity, 4, 3-16 [in Ukrainian].

9. Nagovicyn, A.E. (2005). Features of the rhythmic-phonetic structure of the text: Semantic content Phonetic signs [Osobennosti ritmofoneticheskoj struktury teksta: Smyslovoe napolnenie foneticheskij znakov]. Moskow : MPSI: Flinta [in Russian].

10. Padalka, O.V. (2012). Political speech and its prosodic characteristics [Politychna promova ta yiyi prosodychni kharakterytyky]. Scientific Bulletin of the Volyn National University named after Lesya Ukrainka, 6, 66-69 [in Ukrainian].

11. Petryk, V.M. (Ed.) (2010). Suggestive technologies of manipulative influence [Suhestyvni tekhnolohiyi manipulyatyvnoho vplyvu]. Kyiv: Scientific and Publishing Department of the National Academy of Security Service of Ukraine [in Ukrainian].

12. Pocheptsov, G.G. (2019). Post-truth as a new round of civilization [Postpravda kak novyy vytok razvytyya tsyvylyzatsyy]. URL: https://ms.detector.media/mediaanalitika/post/22902/2019-05-19postpravda-kak-novyi-vitok-razviti (last access: 28.01.2021) [in Russian]. 
13. Samoilova, I.V. \& Podvoyska, O.V. (2016). Lexical features of political speeches [Leksychny osoblyvosti politychnykh promov]. Scientific notes of NDU named after M. Gogol. Philological sciences, 1, 235-238 [in Ukrainian].

14. Snytko, O.S. (2016). Information-psychological online confrontation in the paradigms of linguistics of influence [Informatsiynopsykholohichne onlayn protystoyannya u paradyhmakh linhvistyky vplyvu]. Comparative studies of Slavic languages and literatures, 31, 121-136 [in Ukrainian].

15. Cherepanova, I.Yu. (1995). Man manipulating (suggestion in communication) [Chelovek manipuliruyushchiy (suggestiya $\mathrm{v}$ kommunikatsii)]. Language, culture, knowledge, 115-124 [in Russian].

16. Brown, G. (1983). Discourse Analysis. Cambrige: Cambrige Univ. Press. [in English].

17. Jacobsen, K. \& Kerry, T. (2020). "The right to lead": Navajo language, dis-citizenship, and Diné presidential politics. Journal of Sociolinguistics, 24(1), 35-54. https://doi.org/10.1111/josl.12380 [in English]. 